\title{
MANAJEMEN LABA, PENGUNGKAPAN CORPORATE SOCIAL RESPONSIBILITY DAN SUSTAINABILITY REPORTING PERUSAHAAN MANUFAKTUR DI BEI
}

\author{
Sofiani Murni \\ Sri Ayem \\ Program Studi Akuntansi \\ Fakultas Ekonomi, Universitas Sarjanawiata Tamansiswa \\ Email korespondensi: yanimurni@yahoo.com
}

\begin{abstract}
The aim of this research is to obtain empirical evidence about the effects of earnings management and disclosure of Corporate Social Responbilty to Sustainability Reporting. Corporate Social Responbilty calculated with a control variable that is leverage, Growth, Roa and Sustainability Reporting projected with sustainability reporting disclosure index with is based on reporting standards Global Reporting Initiative (GRI) that the company discloses in annual reports and ongoing reports. The population in this study is all sub-sectors of manufacturing companies in Indonesia stock exchange (BEI). The total sample is 100 companies selected using the purposive sampling method issued annual reports for the period 2014-2018. Data to be tested using multiple linear regression analysis. The results of this research are: (1) Earnings management has a significant positive effect on sustainability reporting. (2) Leverage positively influences sustainability reporting. (3) Growth growth has a positive effect on sustainability reporting. (4) ROA has a positive effect on sustainability reporting.
\end{abstract}

Keywords: earning management leverage, growth, ROA, sustainability reporting

\begin{abstract}
ABSTRAK
Penelitian ini bertujuan untuk memperoleh bukti empiris mengenai pengaruh Manajemen Laba dan Pengungkapan Corporate Social Responsibility terhadap Sustainability Reporting. Corporate Social Responsibility dihitung dengan variabel control yaitu leverage, growth, ROA dan sustainability reporting diproyeksikan dengan sustainability reporting disclosure index yang didasarkan pada standar pelaporan Global Reporting Intitative (GRI) yang diungkapkan perusahaan dalam laporan tahunan dan laporan berkelanjutan. Populasi dalam penelitian adalah semua sub sector perusahaan manufaktur di bursa efek Indonesia (BEI). Total sampel adalah 100 perusahaan yang dipilih menggunakan metode purposive sampling yang mengeluarkan laporan tahunan selama periode tahun 2014-2018. Data untuk diuji dengan menggunakan analisis regresi linear berganda. Hasil dari penelitian ini adalah: (1) Manajemen laba berpengaruh positif signifikan terhadap sustainability reporting, (2) Leverage berpengaruh positif terhadap sustainability reporting, (3) Growth berpengaruh positif terhadap sustainability reporting. (4) ROA berpengaruh positif terhadap sustainability reporting.
\end{abstract}

Kata kunci: manajemen laba, leverage, growth, $R O A$, sustainability reporting 


\section{PENDAHULUAN}

Untuk melakukan suatu bisnis pada suatu perusahaan, pastiakan perusahaan tersebut harus memiliki tanggungjawab bagi suatu pemangku kepentingan, baik jika itu dari pihak internal maupun dari pihak eksternal dalam suatu perusahaan tersebut. Pemangku kepentingan atau biasa disebut dengan stakeholders yang sering terlibat pada sebuah bisnis dalam perusahaan seperti seorang pemilik atau pemegang saham, kreditor, karyawan, pemasok, konsumen, komunitas, serta lingkungannya itu sendiri. Kaitan antara Corporate social responbilty dengan sustainability reporting yaitu untuk mewujudkan prilaku dan bentuk prilaku yang sama dengan pembangunan berkelanjutan untuk kesejahteraan masyarakat dan untuk memperhatikan kondisi sosial, lingkungan, dan pembangunan ekonomi yang dilaksanakan secara berkelanjutan. Sedangkan kaitan antara manajemen laba terhadap sustainability reporting yaitu untuk pembangunan berkelanjutan ekonomi di perusahaan untuk masa jangka panjang yang lebih baik dan hitungan pada akuntansi yang tidak sesuai dengan kondisi pada sebuah ekonomi dalam perusahaan, jadi pembangunan berkelanjutan harus dilakukan dalam sebuah perusahaan agar tidak menyesatkan pihak investor dalam mengambil suatu tindakan keputusan ekonomi dengan adanya angka atau laba dalam perusahaan tersebut yang menggunakan laporan berkelanjutan.

Untuk mengukur CSR yaitu dengan menggunakan tiga variabel kontrol yaitu leverage, growth, ROA (Return on Assets). Jansen dan Meckling (2015) menjelaskan leverage merupakan alat untuk mengukur seberapa sebuah perusahaan tergantung pada kreditur dalam membiayai asset perusahaan. Perusahaan yang mempunyai tingkat leverage tertinggi berarti sangat tergantung pada pinjaman luar yaitu untuk membiayai assetnya sedangkan perusahaan yang mempunyai nilai tingkat leverage rendah lebih banyak membiayai assetnya dengan modal sendiri, tingkat leverage perusahaan dengan demikian menggambarkan resiko perusahaan keuangan. Sedangkan Carvalho dan Costa (2014) menyatakan growth yaitu menggambarkan peningkatan penjualan dari tahun ke tahun dan tingginya tingkat sales growth menunjukan semakin baik suatu perusahaan dalam menjalanakan operasinya, dan bagaimana di dalam suatu perusahaan yang menggunakan growth ini bisa menegatahui peningkatan penjualan di dalam perusahaan mereka, sedangkan Kasmir (2014) menjelaskan bahwa ROA yaitu mampu mengukur kemampuan perusahaan dalam menghasilkan keuntungan pada masa lampau untuk kemudian diproyeksikan dimasa yang akan datang return on assets ini rasio yang bisa menunjukan hasil atas jumlah aktiva yang digunakan dalam perusahaan. Hal ini dapat dilihat pada Undangundang No.40 mengenai Perseroan Terbatas pasal 74 yang menjelaskan bahwa perusahaan yang menjelaskan tentang suatu kegiatan usaha di bidang atau yang berkaitan dengan sumber daya alam wajib melakukan tanggung jawab sosial dan lingkungan jadi Dengan menerapkan corporate social responsibility ini, perusahaan bisa menciptakan suatu image yang baik sehingga membuat sebuah penilaian positif dari masing-masing pemangku kepentingan. manajemen dalam perusahaan juga dapat memberikan kebijakan dalam penyusunan laporan keuangan untuk mencapai tujuan tertentu. Hal ini dikarenakan proses penyusunan laporan keuangan dipengaruhi oleh faktor-faktor tertentu yang dapat menentukan kualitas laporan keuangan.

Susanto dan Ramadhani (2016) menjelaskan bahwa suatu pilihan dalam mengambil sebuah kebijakan akuntansi yang dilakukan oleh seorang manajer yaitu untuk tujuan yang tertentu itulah yang disebut dengan manajemen laba. Jadi pihak manajemen laba ini ingin memberikan suatu fleksibilitas bagi para manajer untuk melindungi diri maupun pada perusahaan dalam mengantisipasi suatu kejadian-kejadian yang tak terduga untuk keuntungan pihak-pihak yang terlibat dalam suatu kontrak. Adiwibowo (2018) menjelaskan tentang manajemen laba yaitu sebagai tindakan untuk seorang manajer dalam melakukan suatu kebijakan akuntansi yaitu terhadap suatu peloparan angka-angka akuntansi yang tidak sesuai dengan suatu kondisi didalam sebuah ekonomi perusahaan yang sebenarnya dan tidak menyesatkan seorang pihak investor untuk mengambil keputusan ekonomi dengan adanya suatu angka laba tersebut. Dengan adanya peraturan ini menurut national center for sustainanbilty reporting (NCSR), sustainability 
di Indonesia terus berkembang tetapi jumlah perusahaan di Indonesia yang melaporkan sustainability report masih jauh tertinggal di bandingkan dengan negara maju, padahal pelaporan kegiatan berkelanjutan dalam sustainability report terbukti berkorelasi positif terhadap kinerja keuangan perusahaan. Weber dalam Lesmana dan Tarigan, 2014) menyatakan bahwa Global Reporting Intitative (GRI) merupakan salah satu dari lembaga yang serius menangani permasalahan yang berhubungan dengan sustainability. Wibowo dan Faradiza (2014) menjelaskan bahwa GRI berdiri yaitu karena semakin mendesaknya transparansi pengaruh aktivitas bisnis perusahaan baik ekonomi, lingkungan, sosial sehingga dibutuhkan pedoman atau framework untuk menyusun sustainability report bagi perusahaan dalam berbagai ukuran dan sektor usaha di seluruh dunia.

\section{KAJIAN TEORI}

\section{Teori Keagenan}

Menurut Jensen Meckling dan Wijayanti (2015), salah satu konsep dari manajemen laba yang digunakan adalah pendekatan teori keagenan atau biasa disebut dengan agency theory yang menjelaskan bahwa menggambarkan suatu hubungan dengan keagenan yang muncul ketika satu orang atau lebih yang disebut dengan (prinsipal) meminta kepada orang lain atau agen untuk melakukan suatu pekerjaan dan mendelagasikan wewenang pembuatan keputusan tersebut kepada agen.

\section{Teori Legimitasi}

Teori legitimasi adalah suatu gagasan tentang bagaimana kontrak sosial antara perusahaan dengan masyarakat. Menurut teori ini, untuk diterima oleh masyarakat, suatu perusahaan harus mengungkapkan bagimana aktivitas sosial perusahaan sehingga akan menjamin kelangsungan hidup perusahaan Wibowo dan Faradiza (2014).

\section{Manajemen Laba}

Scott (2015) menyatakan bahwa manajemen laba sebagai perilaku oportunistis manajer untuk memaksimalkan utilitasnya dalam menghadapi kontrak kompensasi, kontrak utang dan political costs. manajemen laba memberi manajer suatu fleksibilitas untuk melindungi diri mereka dan perusahaan dalam mengantisipasi kejadian-kejadian yang tak terduga untuk keuntungan pihak-pihak yang terlibat dalam kontrak.

\section{Teori Persinyalan (Signalling Theory)}

Teori persinyalan membahas yaitu tentang dorongan suatu perusahaan untuk memberikan sebuah informasi kepada pihak eksternal.

\section{Teori Stakeholder}

Stakeholder yaitu semua pihak baik internal maupun eksternal yang memiliki suatu hubungan yang baik yang bersifat mempengaruhi maupun dipengaruhi, bersifat langsung maupun tidak langsung dari perusahaan.

\section{Leverage}

Gitusudarmo (2015) mengatakan seberapa besar biaya tetap operasi perusahaan merupakan bagian dari biaya total operasi suatu perusahaan seperti biaya tetap pabrikasi, biaya administrasi, dan biaya penjualan. Perjanjian terbatas seperti perjanjian hutang yang tergambar dalam tingkat leverage dimaksudkan membatasi kemampuan manajemen untuk menciptakan transfer kekayaan antar pemegang obligasi.

\section{Growth}

Adnan (2014) menjelaskan bahwa salah satu indikator dalam kemampuan perusahaan untuk peningkatan sebuah kinerja penciptaan pendapatan pada sebuah perusahaan. Growth opportunity yaitu menjelaskan bagaimana suatu prospek pertumbuhan pada suatu perusahaan untuk jangka waktu yang panjang.

\section{Return on Assets (ROA)}

Tyas (2018) menyatakan bahwa profitabilitas menunjukan kemampuan perusahaan untuk mendapatkan laba pada tingkat tertentu. Perusahaan mengganggap profitabilitas sebagai tolok ukur utama efisiensi. Rasio profitabilitas mewujudkan kemampuan suatu perusahaan untuk menghasil 
yaitu laba yang relative tehadap suatu penjualan, asset dan ekuitas.

\section{Sustainability Reporting}

Sebagai praktik untuk mengukur dan pengungkapan aktivitas perusahaan sebagai tanggung jawab kepada seluruh stakeholders mengenai kinerja kepada organisasi dalam mewujudkan suatu tujuan yaitu pembangunan berkelanjutan atau disebut dengan sustainability report yang akan menjadi salah satu media untuk mendeskripsikan pelaporan ekonomi, lingkungan dan dampak sosial (seperti halnya konsep triple bottom line, pelaporan CSR, dsb.

Tabel 1. Penelitian Terdahulu

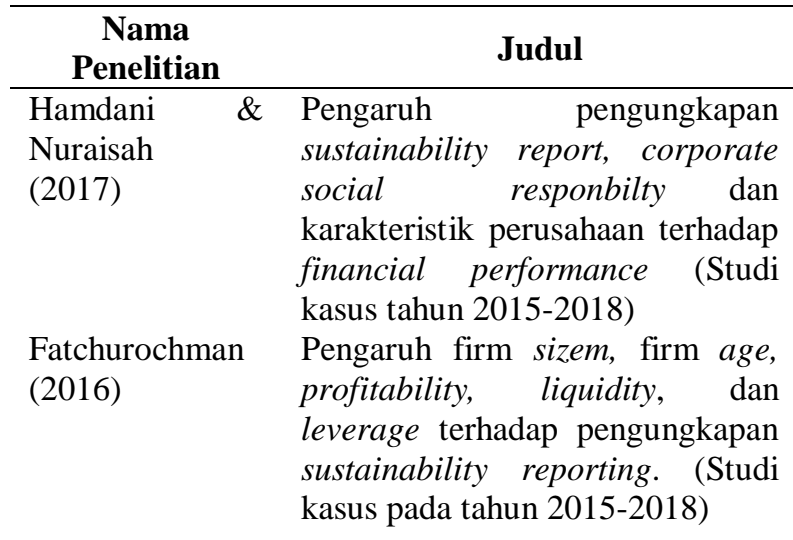

\section{Pengaruh Manajemen Laba terhadap Sustainability Reporting}

Sudaryono (2014) yang meneliti tentang anteseden manajemen laba dan konsekuensinya terhadap laporan korporasi berkelanjutan (corporate sustainability reporting). Hasil hipotesis dari penelitian ini yaitu manajemen laba berpengaruh positif terhadap laporan berkelanjutan korporasi kajian terdahulu mengenai dampak manajemen laba terhadap sustainability reporting masih terbatas mengenai hal ini. Manajemen merupakan tindakan dari manajer memanipulasi laporan keuangan sehingga laba yang dihasilkan tampak baik.

H1 = Manajemen laba berpengaruh positif terhadap sustainability reporting

\section{Pengaruh Pengungkapan Leverage terhadap Sustainability Reporting}

Carroll \& Shabana (2016) menemukan bahwa kinerja lingkungan tidak mempengaruhi nilai pasar perusahaan. Dalam pelaksanaan sustainability reporting, perusahaan perlu memahami kesesuaian antara aktivitas triple bottom line dengan kondisi sosial disekitarnya. Hanya ketika perusahaan mampu melaksanakan aktivitas CSR yaitu leverage yang mendapat dukungan dari pemangku

\section{Hasil Penelitian}

Berdasarkan hasil dari analisis penelitian ditemukan bahwa pengungkapan laporan berkelanjutan atau sustainability reporting, corporate social responbilty dan karakteristik perusahaan berpengaruh positif dan signifikan terhadap financial performance

Berdasarkan hasil dari penelitian menggunakan analisis linear berganda bahwa firm size,firm age, dan leverage berpengaruh signifikan positif terhadap sustainability reporting sedangkan profitability, liquidty berpengaruh signifkan terhadap sustainability reporting

kepentingan yang akan memberikan keuntungan bagi perusahaan ini berarti bahwa leverage berpengaruh positif terhadap sustainability reporting karena memberikan keuntungan pada perusahaan yang menggunakan laporan berkelanjutan

$\mathrm{H} 2$ = Leverage berpengaruh signifikan yang positif terhadap sustainability reporting.

\section{Pengaruh Pengungkapan Growth terhadap Sustainability Reporting}

Pada penelitian Danchev (2015)
disebutkan bahwa kerja organisasi
digabungkan dengan pertumbuhan dan prilaku
berkelanjutan, ide di balik ini adalah kenyataan
bahwa seorang manajer dapat menerapkan
suatu kegiatan sosial perusahaan kedalam
tujuan strategi untuk bisa mencapai
pertumbuhan yang berkelanjutan, pada status
masing-masing dalam rantai nilai kegiatan
sosial perusahaan. Perusahaan dengan
pertumbuhan jangka panjang yang lebih baik
mungkin mempublikasikan jangka panjang.
Jadi, growth berpengaruh positif terhadapat
sustainability reporting.

H3 = Growth berpengaruh positif tterhadap sustainability reporting. 


\section{Pengaruh Pengungkapan ROA terhadap Sustainability Reporting}

Penelitian yang dilakukan oleh Burhan dan Rahmanti (2015), sustainability reporting ditujukan sebagai bentuk bukti bertanggungjawaban perusahaan terhadap stakeholders dan bukti bahwa perusahaan berada dalam batasan peraturan yang ada. Jadi bisa menyimpulkan bahwa pengungkapan sustainability reporting memilki hubungan signifikan dan berpengaruh positif terhadap kinerja perusahaan. Hal ini menunjukan bahwa sustainability report dapat memebrikan pengaruh positif terhadap kinerja perusahaan, dimana semakin terpenuhinya indeks pengungkapan maka kinerja perusahaan juga meningkat, berdasarkan uraian tersebut maka hipotesis dalam penelitian ini adalah sebagai berikut

H4 = ROA Berpengaruh positif terhadap sustainability reporting.

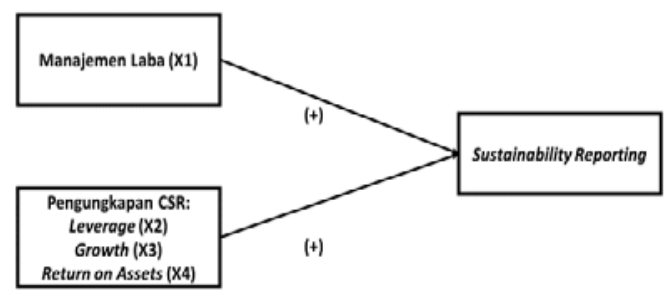

Gambar 1. Kerangka Pemikiran

\section{METODE}

\section{Populasi dan Sampel}

Populasi dalam peneliti ini adalah perusahaan-perusahaan yang termasuk dalam sektor manufaktur di bursa efek Indonesia periode tahun 2014-2018 yang di ambil 20 perusahaan sebagai objek peneliti dan total sampel perusahaan manufaktur yang diambil diberbagai sub sektor yang terdaftar di BEI yang akan dianalisis sebanyak 100 sampel.

\section{Analisis Regresi Linear}

Uji regresi linear berganda penelitian ini menggunakan analisis regresi linear berganda digunakan untuk menganalisis kekuatan hubungan antara dua variabel atau lebih, selain itu analisis ini dapat digunakan untuk menunjukkan arah hubungan antara variabel depanden dan variabel independen (Ghozali, 2011).

Model persamaan regresi yang akan diuji dalam penelitian ini adalah:

$\breve{\mathrm{y}}=\mathrm{a}+\mathrm{b} 1 \mathrm{X} 1+\mathrm{b} 2 \mathrm{X} 2+\mathrm{b} 3 \mathrm{X} 3+\mathrm{b} 4 \mathrm{X} 4+\mathrm{e}$

Keterangan:

y̆: Prediksi sustainability reporting

a: Konstanta

$\mathrm{X} 1$ : Discretionary accrual

$\mathrm{X}$ 2: leverage

X3: Growth

X4: Return on assets

b1,2,3,4: besaran koefisien regresi dari masing-masing variabel

$\varepsilon:$ Error item

Tabel 1. Definisi Operasional

\begin{tabular}{|l|l|}
\hline \multicolumn{1}{|c|}{ Variabel } & \multicolumn{1}{|c|}{ Keterangan Ukuran Rumus } \\
\hline $\begin{array}{l}\text { Sustainability reporting disclosure indeks } \\
(Y)\end{array}$ & $\mathrm{SRDI}=\frac{n}{k}$ \\
\hline Discretionary accrual $(\mathrm{X} 1)$ & $D A_{i t}=$ Tait/ $\mathrm{A}_{\mathrm{it}}-\mathrm{NDA}_{\mathrm{it}}$ \\
\hline Leverage $(X 2)$ & $\mathrm{LEV}=\frac{\text { total utang }}{\text { total ekuitas }}$ \\
\hline Growth $(X 3)$ & $\mathrm{MB}=\frac{\text { Market value of equity }}{\text { book value of equity }}$ \\
\hline Return on assets $(\mathrm{ROA})(\mathrm{X} 4)$ & $\mathrm{ROA}=\frac{\text { net profit }}{\text { total sale }} \times 100$ \\
\hline
\end{tabular}




\section{HASIL}

Manajemen laba terdapat nilai minimum sebesar -989684 atau $-989,684$ dan nilai maximum sebesar 1.02065 atau 120,65 nilai rata-rata dari manajemen laba pada perusahaan manufaktur diberbagai sub sektor yang terdaftar di Bursa Efek Indonesia tahun 20142018 sebesar -2.9105664 dengan nilai standar deviasinya adalah 4.42728354 maka dapat disimpulkan bahwa nilai rata-rata manajemen laba lebih besar daripada nilai standar deviasinya tidak bersifat homogen.

Leverage terdapat nilai minimum sebesar 0,0060 atau 0,60 dan nilai maximum sebesar 1.5717 atau 157,17 dan nilai rata-rata dari leverage pada perusahaan bursa efek Indonesia tahun 2014-2018 sebesar 0.379443 atau 379,443 dengan nilai standar deviasinya adalah sebesar 0.3570343 atau 357,343 Maka dapat diketahui bahwa nilai rata-rata lebih besar dari pada nilai standar deviasi dan hal ini menunjukkan bahwa data ukuran perusahaan bersifat homogen.
Growth terdapat nilai minimum sebesar 0,0020 atau 0,02 dan nilai maximum sebesar 1.8866 atau 18,866 dan nilai rata-rata sebesar 0.331657 atau 331,657 dengan nilai standar deviasinya adalah sebesar 0.3603846 atau 360,846. Maka dapat diketahui bahwa nilai rata-rata lebih kecil daripada nilai standar deviasinya.

ROA terdapat nilai minimum sebesar 0.0001 atau 0.01 dan nilai maximumnya sebesar 1.9320 atau 19,320 dan nilai rata-rata sebesar 0.241072 atau 241,72 dengan nilai standar deviasinya adalah sebesar 0.3271535 atau 327,535. Maka dapat disimpulkan bahwa nilai rata-rata lebih kecil dibandingkan dengan nilai standar deviasinya.

Sustainabilty reporting terdapat nilai minimum sebesar 32.044 atau 32,44 dengan nilai maximum sebesar 39.033 atau 39,33 dan nilai rata-rata yaitu sebesar 3.532891 atau 353,289,1 dengan nilai standar deviasinya yaitu 1.908860 atau 196,86 jadi dapat diketahui bahwa nilai rata-rata lebih besar dari pada nilai standar deviasi dan hal ini menunjukkan bahwa data ukuran perusahaan bersifat homogen.

\begin{tabular}{lcrrrr}
\hline \multicolumn{6}{c}{ Tabel 2. Statistik Deskriptif } \\
\hline & $\mathrm{N}$ & \multicolumn{1}{c}{ Minimum } & \multicolumn{1}{l}{ Maximum } & \multicolumn{1}{c}{ Mean } & \multicolumn{1}{c}{ Std. Deviation } \\
\hline Manajemen Laba & 100 & -98968.0000 & 102059.0000 & -29105.660000 & 44272.8350246 \\
Leverage & 100 & .0060 & 1.5717 & .379443 & .3570343 \\
Growth & 100 & .0002 & 1.8866 & .331657 & .3603846 \\
ROA & 100 & .0001 & 1.9320 & .241072 & .3271535 \\
Sustainability reporting & 100 & 32.044 & 39.033 & 35.32890 & 1.908860 \\
Valid N (listwise) & 100 & & & &
\end{tabular}

Tabel 3. Uji Normalitas

\begin{tabular}{llr}
\hline \multicolumn{2}{c}{ One-Sample Kolmogorov-Smirnov Test } \\
\hline $\mathrm{N}$ & & Unstandardized Residual \\
Normal & Mean & 100 \\
Parameters $^{\mathrm{a}}$ & Std. Deviation & .0000000 \\
Most Extreme & Absolute & 1.87212844 \\
Differences & Positive & .125 \\
& Negative & .125 \\
Kolmogorov-Smirnov Z & -.077 \\
Asymp. Sig. (2-tailed) & 1.254 \\
\hline
\end{tabular}

a. Test distribution is Normal.

Berdasarkan hasil analisis data dengan SPSS 16.00 , nilai kualitas data $086>0,5$ atau
$(0,05)$. Dengan demikian dapat disimpulkan bahwa kualitas data tersebut terdistribusi 
normal dan dapat diproses kembali lebih lanjut. Selain menguji kualitas normalitas data pada tabel 4.2 peneliti juga menganalisis uji normalitas pada gambar 4.3 yaitu uji normalitas probability plot of regression standardized residual di atas. Dan hasilnya data tersebut menunjukkan normal. Dikatakan normal jika data ploting (titik-titik) yang menggambarkan data sesungguhnya mengikuti garis diagonal. Maka dari itu, data yang diperoleh sampel dari tiap-tiap populasi terbukti normal.

Tabel 4. Uji Multikolinearitas

\begin{tabular}{lcc}
\hline & \multicolumn{2}{c}{ Collinearity Statistics } \\
\cline { 2 - 4 } & Tolerance & \multicolumn{2}{c}{ VIF } \\
\hline (Constant) & & 1.090 \\
Manajemen Laba & .918 & 1.048 \\
Leverage & .954 & 1.103 \\
Growth & .906 & 1.107 \\
ROA & .904 & \\
\hline
\end{tabular}

Tabel 5. Uji Heterokedastisitas Coefficients $^{a}$

\begin{tabular}{|c|c|c|c|c|c|c|c|c|}
\hline & \multirow{2}{*}{ Model } & \multicolumn{2}{|c|}{$\begin{array}{l}\text { Unstandardized } \\
\text { Coefficients }\end{array}$} & \multirow{2}{*}{$\begin{array}{c}\text { Standardized } \\
\text { Coefficients } \\
\text { Beta }\end{array}$} & \multirow{2}{*}{$T$} & \multirow{2}{*}{ Sig. } & \multicolumn{2}{|c|}{ Collinearity Statistics } \\
\hline & & B & $\begin{array}{l}\text { Std. } \\
\text { Error }\end{array}$ & & & & Tolerance & VIF \\
\hline \multirow[t]{5}{*}{1} & (Constant) & 34.962 & .406 & & 86.218 & .000 & & \\
\hline & $\begin{array}{l}\text { Manajemen } \\
\text { Laba }\end{array}$ & .000 & .000 & .007 & .068 & .034 & .918 & 1.090 \\
\hline & Leverage & .159 & .551 & .030 & .288 & .023 & .954 & 1.048 \\
\hline & Growth & 1.073 & . 560 & .203 & .034 & .003 & .906 & 1.103 \\
\hline & ROA & .167 & .618 & .029 & .270 & .022 & .904 & 1.107 \\
\hline
\end{tabular}

Berdasarkan dari hasil analisis data, variabel bebas dalam model regresi tidak saling berkolerasi. Kemudian nilai tolerance berada diatas 0,10 dan nilai VIFnya untuk masingmasing variabel kurang dari 10 . Dengan hasil tersebut sebagai bukti bahwa tidak adanya korelasi antar sesama variabel bebas dalam model regresi sehingga dapat disimpulkan nilai yang dihasilkan tidak memiliki masalah multikolinieritas diantara sesama variabel bebas dalam model regresi yang sudah dianalisis.
Hasil analisis juga menunjukkan bahwa manajemen laba memiliki nilai sig 0,034>0,05 kemudian untuk leverage memiliki nilai sig sebesar 0,023>0,05 dan untuk variabel growth memilki nilai sig $0,003>0,05$ sedangkan variabel Roa memiliki nilai sig sebesar 0,022>0,05 Dari hasil pengkajian tersebut maka dapat disimpulkan bahwa variabel yang telah diuji mengandung heterokedastisitas. Artinya ada korelasi antara besarnya data dengan residual sehingga jika data diperbesar tetap tidak akan menyebabkan kesalahan.

Tabel 6. Uji Autokorelasi

\begin{tabular}{lrrrrr}
\hline Model & R & R Square & $\begin{array}{l}\text { Adjusted R } \\
\text { Square }\end{array}$ & $\begin{array}{l}\text { Std. Error of } \\
\text { the Estimate }\end{array}$ & $\begin{array}{l}\text { Durbin- } \\
\text { Watson }\end{array}$ \\
\hline 1 & $.195^{\mathrm{a}}$ & .038 & -.002 & 1.911135 & .426 \\
\hline
\end{tabular}

Berdasarkan hasil analisis data, hasil uji autokorelasi dengan menggunakan uji durbin watson. Terlihat nilai DW sebesar 426, sehingga nilai ini akan dilakukan perbandingan 
dengan nilai tabel menggunakan derajat kepercayaan yakni 5\%, jumlah sampel 100 dan jumlah variabel bebas 4 , yang didapatkan nilai DL sebesar 1,5922dan nilai DU sebesar 1,7582 sehingga, DU $<$ DW < 4-DL 2.0478 dan nilai 4DU sebesar 2,2418 artinya dapat disimpulkan bahwa model regresi tersebut tidak terjadi autokorelasi.

Tabel 7. Hasil Uji Regresi

Coefficients $^{\mathrm{a}}$

\begin{tabular}{|c|c|c|c|c|c|c|}
\hline & \multirow[t]{2}{*}{ Model } & \multicolumn{2}{|c|}{$\begin{array}{l}\text { Unstandardized } \\
\text { Coefficients }\end{array}$} & \multirow{2}{*}{$\begin{array}{c}\text { Standardized } \\
\text { Coefficients } \\
\text { Beta } \\
\end{array}$} & \multirow[t]{2}{*}{$\mathbf{T}$} & \multirow[t]{2}{*}{ Sig. } \\
\hline & & B & Std. Error & & & \\
\hline \multirow{5}{*}{1} & (Constant) & 34.962 & .406 & & 86.218 & .000 \\
\hline & Manajemen Laba & .000 & .000 & .007 & .068 & .034 \\
\hline & Leverage & .159 & .551 & .030 & .288 & .023 \\
\hline & Growth & 1.073 & .560 & .203 & .034 & .003 \\
\hline & ROA & .167 & .618 & .029 & .270 & .022 \\
\hline
\end{tabular}

Berdasarkan hasil analisis data di atas, dapat dilihat bahwa Manajemen Laba bersignifikan 0,034 > 0,05 Kemudian untuk variabel Leverage hasilnya signya yaitu sebesar 0,023>0,05 dan untuk variabel Growth sebesar $0,003>0,05$ sedangkan hasil dari variabel ROA yaitu $0,022>0,05$ dilihat dari hasil tersebut dapa disimpulkan bahwa Sustainability Reporting dipengaruhi oleh manajemen laba dan pengungkapan Corporate Social Responsibility.

\section{Pembahasan Hasil Penelitian}

Berdasarkan pada tabel uji $\mathrm{F}$ berikut, dapat dijelaskan bahwa nilai signifikan untuk pengaruh manajemen laba dan pengungkapan leverage, growth, ROA terhadap sustainability reporting sebesar 0,004 $<0,05$ dan nilai $\mathrm{F}$ hitung $0.941>$ F-tabel 2,38 sehingga data tersebut dapat disimpulkan bahwa tiap variabel bebas atau variabel $\mathrm{x}$ memiliki pengaruh simultan yang signifikan antara manajemen laba, leverage, growth, ROA terhadap sustainability reporting.

Tabel 8. Hasil Uji F

ANOVA $^{b}$

\begin{tabular}{llrrrrr}
\hline \multicolumn{1}{c}{ Model } & \multicolumn{1}{c}{$\begin{array}{c}\text { Sum of } \\
\text { Squares }\end{array}$} & df & Mean Square & F & \multicolumn{1}{c}{ Sig. } \\
\hline 1 & Regression & 13.749 & 4 & 3.437 & .941 & $.004^{\text {a }}$ \\
& Residual & 346.982 & 95 & 3.652 & & \\
Total & 360.731 & 99 & & & \\
\hline
\end{tabular}

a. Predictors: (Constant), roa, leverage, manajemen laba, growth

Pengaruh Manajemen Laba terhadap

Sustainability Reporting

Hasil pengujian hipotesis yang sudah di analisis akan digunakan sebagai bukti bahwa pengaruh manajemen laba terhadap sustainability reporting berdasarkan dari uji $\mathrm{t}$ yang sudah di analisis melalui SPSS 16, mendapat perolehan nilai signifikan 0,034 > 0,05 dan koefisien $\beta$ sebesar 0,007 dengan arah yang posistif hal ini menyimpulkan bahwa manajemen laba berpengaruh positif terhadap sustainability reporting.

Pengaruh Leverage terhadap Sustainability Reporting

Hasil pengujian hipotesis yang sudah di analisis akan digunakan sebagai bukti bahwa pengaruh leverage terhadap sustainability reporting berdasarkan dari uji t yang sudah di analisis melalui SPSS 16, mendapat perolehan nilai signifikan $0,023>0,05$ dan koefisien $\beta$ 
sebesar 0,030 dengan arah yang posistif hal ini menyimpulkan bahwa leverage berpengaruh positif terhadap sustainability reporting.

\section{Pengaruh Growth terhadap Sustainability Reporting}

Hasil pengujian hipotesis yang sudah di analisis akan digunakan sebagai bukti bahwa pengaruh growth terhadap sustainability reporting berdasarkan dari uji t yang sudah di analisis melalui SPSS 16, mendapat perolehan nilai signifikan $0,003>0,05$ dan koefisien $\beta$ sebesar 0,203 dengan arah yang posistif hal ini menyimpulkan bahwa growth berpengaruh positif terhadap sustainability reporting

\section{Pengaruh ROA terhadap Sustainability} Reporting

Hasil pengujian hipotesis yang sudah di analisis akan digunakan sebagai bukti bahwa pengaruh roa terhadap sustainability reporting berdasarkan dari uji t yang sudah di analisis melalui SPSS 16 , mendapat perolehan nilai signifikan $0,022>0,05$ dan koefisien $\beta$ sebesar 0,029 dengan arah yang posistif hal ini menyimpulkan bahwa roa berpengaruh positif terhadap sustainability reporting.

\section{PEMBAHASAN}

Hasil penguji $\mathrm{H} 1$ mendukung dilihat dari nilai manajemen laba berpengaruh positif terhadap sustainanbilty reporting. hal ini menunjukkan bahwa nilai $\mathrm{t}$ hitung $<\mathrm{t}$ tabel $0.068<2,005$ memiliki signifikan $0.034>0,05$ dan koefisien $\beta \quad 0,007$ dengan arah positif. Dengan demikian, dapat kita katakan bahwa variabel manajemen laba memiliki pengaruh terhadap sustainability Reporting.

Hasil pengujian $\mathrm{H} 2$ mendukung dilihat dari nilai leverage berpengaruh positif terhadap sustainability reporting. Hal ini menunjukan bahwa nilai t hitung $<$ t table $0.288<2,005$ memiliki signifikan $0.023>0,05$ dan koefisien $\beta 0,030$ dengan arah positif. Dengan demikian dapat kita katakan bahwa variabel leverage memiliki pengaruh terhadap sustainability reporting.

Hasil pengujian $\mathrm{H} 3$ mendukung terlihat dari growth berpengaruh positif hal ini menunjukan bahwa nilai t hitung $<$ t table 0,034 $<2,005$ memiliki signifikan $0.003>0,05$ dan koefisien $\beta 0,203$ dengan arah positif. Dengan demikian dapat kita katakan bahwa variabel leverage memiliki pengaruh terhadap sustainability reporting.

Hasil pengujian $\mathrm{H} 4$ mendukung terlihat dari ROA berpengaruh menunjukan bahwa nilai t hitung $<\mathrm{t}$ table $-0.270<2,005$ memiliki signifikan $0.022>0,05$ dan coefficient $\beta 0,029$ dengan arah positif. Dengan demikian, dapat kita katakan bahwa variabel ROA memiliki pengaruh terhadap sustainability reporting.

\section{SIMPULAN, KETERBATASAN, DAN SARAN}

Manajemen laba berpengaruh terhadap sustainability reporting. Hal ini dapat dijelaskan bahwa semakin manajer melakukan perataan laba terhadap perusahaan maka perusahaan tersebut akan memberikan keuntungan yang baik pada laporan berkelnjutan untuk jangka panjang. Seperti hasilnya pengujian bahwa dikatakan, bahwa manajemen laba berpengaruh positif terhadap sustainability reporting. Hal ini menunujukan bahwa nilai $\mathrm{t}$ hitung $<\mathrm{t}$ table $0,068<1.98525$ memiliki signifikan 0,034 >0,05 dan koefisien $\beta$ sebesar 0,007 dengan arah positif dengan demikian dapat dikatakan bahwa variabel manajemen laba berpengaruh positif terhadap sustainability reporting.

Leverage berpengaruh terhadap sustainability reporting. Hal ini dapat dijelaskan bahwa dengan adanya corporate social responbility maka perusahaan tersebut dapat terlaksana dengan baik dan mendorong perusahaan untuk melaksanakan tanggungjawab perusahaan dengan menggunakan leverage yang tinggi sangat tergantung pada kepercayaan dan dukungan dari para kreditor dalam laporan berkelanjutan. Seperti hasil pengujiannya bahwa dikatakan leverage menunjukkan bahwa nilai t hitung $<\mathrm{t}$ table $0,288<1.98525$ memiliki signifikan $0,023>0,005$ dan koefisien $\beta 0,030$ dengan arah positif dengan demikian leverage berpengaruh positif terhadap sustainability reporting.

growth berpengaruh terhadap sustainability reporting, hal ini dijelaskan growth yang dihadapi perusahaan diwaktu yang akan datang merupakan suatu prospek baik yang dapat mendatangkan laba bagi perusahaan. Seperti hasil pada pengujiannya bahwa dikatakan growth menunjukan bahwa nilai $\mathrm{t}$ hitung $<\mathrm{t}$ 
table $0,034<1.98525$ memiliki nilai signifikan $0,003>0,005$ dan koefisien $\beta 0,203$ dengan arah positif dengan demikian growth berpengaruh positif terhadap sustainability reporting.

ROA berpengaruh terhadap sustainability reporting, hal ini dijelaskan karena ROA menghasilkan laba yang yang diharapkan dengan menggunakan semua asset yang dimiliki perusahaan. Seperti hasil pada pengujiannya bahwa dikatakan ROA menunjukan bahwa nilai t hitung $<$ t table 0,270 $<1.98525$ memiliki nilai signifikan 0,022 > 0,005 dan koefisien $\beta 0,029$ dengan arah positif dengan demikian ROA dapat dikatakan berpengaruh positif terhadap sustainability reporting.

\section{Keterbatasan Penelitian}

Penelitian ini telah diusahakan dan dilaksanakan sesuai dengan prosedur ilmiah, akan tetapi masih memilki keterbatasan yaitu Jumlah populasi yang masih sedikit dikarenakan hasil report dari perusahaan yang di ambil dan dianalisis menggunakan SPSS menghasilkan output data normalitas hanya sebanyak 20 perusahaan dari semua perusahaan manufaktur yang terdaftar di Bursa efek Indonesia (BEI) tahun 2014-2018

\section{Saran}

Bagi perusahaan, perusahan perlu menggunakan sustainability reporting untuk mengetahui hasil dari kegiatan operasional sehingga perusahaan dapat memberikan keputusan baik dalam tiap kegiatan operasional baik itu dalam jangka pendek maupun dalam jangka panjang. Dan sebaiknya juga perusahaan yang belum menggunakan sustainability reporting segera menggunakan sustainability reporting karna bisa menjaga nilai perusahaan untuk jangka panjang.

Bagi peneliti selanjutnya dengan menambahkan efektivitas modal kerja agar agar bisa mengetahui kelebihan aktiva lancar terhadap hutang jangka pendek dan bisa mengetahu modal kerja bersih pada perusahaan yang belum menggunakan sustainability reporting.

\section{REFERENSI}

Adiwibowo, A. S. (2018). Pengaruh Manajemen Laba, Ukuran Perusahaan dan Leverage terhadap Return Saham dengan Kebijakan Dividen sebagai Variabel Moderasi. Jurnal Ilmiah Akuntansi Universitas Pamulang.

Andry Priharta, Dewi Puji Rahayu, B. S. (2018). Pengaruh CGPI, Kualitas Audit, Ukuran Perusahaan, dan Leverage Terhadap Manajemen Laba. Journal of Management and Business.

Anggraeni, D. Y., \& Djakman, C. D. (2018). Pengujian Terhadap Kualitas Pengungkapan CSR di Indonesia. Ekuitas (Jurnal Ekonomi Dan Keuangan).

Astari, M. R., \& Suryanawa, I. K. (2017). Faktor Faktor yang mempengaruhi Manajemen Laba. E-Jurnal Akuntansi Universitas Udayana.

Astuti, A. Y., Nuraina, E., \& Wijaya, A. L. (2018). Pengaruh Ukuran Perusahaan dan Leverage terhadap Manajemen Laba. Pendidikan Akuntansi.

Azkia, S., \& Mulyani, S. (2018). Analisis Beda Kualitas Sustainability Reporting Terhadap Nilai Perusahaan. Jurnal SIKAP (Sistem Informasi, Keuangan, Auditing Dan Perpajakan).

Bradford, M., Earp, J. B., Showalter, D. S., \& Williams, P. F. (2017). Corporate sustainability reporting and stakeholder concerns: Is there a disconnect? Accounting Horizons.

Dewi Teresia, E. S., \& Hermi, H. (2016). Pengaruh Struktur Kepemilikan, Ukuran Perusahaan dan Keputusan Keuangan terhadap Nilai Perusahaan dengan Pertumbuhan Perusahaan sebagai Variabel Moderating. Jurnal Magister Akuntansi Trisakti.

Dianawati, W. (2017). Pengaruh Karakteristik Perusahaan dan Sertifikasi Lingkungan terhadap Pengungkapan Corporate Social Responsibility (Csr) di Indonesia. Ekuitas (Jurnal Ekonomi Dan Keuangan). 
Fadjrih Asyik, N. (2016). Perspektif Agency Theory: Pengaruh Informasi Asimetri terhadap Manajemen Laba (Menggunakan Pendekatan Agency Framework). Ekuitas (Jurnal Ekonomi Dan Keuangan).

Fahmi, M., \& Prayoga, M. D. (2018). Pengaruh Manajemen Laba dan Tax Avoidance terhadap Nilai Perusahaan dengan Kualitas Audit Sebagai Variabel Moderasi. Jurnal Pendidikan Akuntansi.

Hamdani, S. P., Yuliandari, W. S., \& Budiono, E. (2017). Pengaruh Kepemilikan Saham Publik dan Return On Assets terhadap Pengungkapan CSR. Jurnal Riset Akuntansi Dan Perpajakan Jrap.

Mariani, W. E., Rasmini, N. K., \& Mimba, N. P. S. H. (2016). Kemampuan Good Corporate Governance Dan Csr Memoderasi Pengaruh Likuiditas, Solvabilitas, Dan Profitabilitas Pada Nilai Perusahaan. E-Jurnal Ekonomi Dan Bisnis Universitas Udayana.

Muallifin, O. R., \& Priyadi, M. P. (2016). Dampak Pengungkapan Sustainability Report terhadap Kinerja Keuangan dan Kinerja Pasar. Jurnal Ilmu Dan Riser Akuntansi.

Mustika, G., Sari, R. N., \& Azhar L, A. (2016). Pengaruh Manajemen Laba terhadap Pengungkapan Corporate Social Responsibility: Variabel Anteseden dan Variabel Moderasi. Akuntabilitas.

Oktariani, N., \& Mimba, N. (2014). Pengaruh Karakteristik Perusahaan dan Tanggung Jawab Lingkungan pada Pengungkapan Tanggung Jawab Sosial Perusahaan. EJurnal Akuntansi.

Putra, B., \& Wirakusuma, M. (2015). Pengaruh Pengungkapan Corporate Social Responsibility pada Nilai Perusahaan dengan Profitabilitas sebagai Pemoderasi. E-Jurnal Akuntansi.

Putri, R. A., \& Christiawan, Y. J. (2014). Pengaruh Profitabilitas, Likuiditas, dan Leverage terhadap Pengungkapan
Corporate Social Responsibility. Business Accounting Review.

Ratmono, D., \& Sagala, W. M. (2016). Pengungkapan Corporate Social Responsibility (CSR) sebagai Sarana Legitimasi: Dampaknya terhadap Tingkat Agresivitas Pajak. Nominal, Barometer Riset Akuntansi dan Manajemen.

Sembiring, C. L. (2017). Manajemen Laba dan Pengungkapan Tanggung Jawab Sosial Perusahaan Dengan Komisaris Independendan Kepemilikan Institusional sebagai Variabel Pemoderasi. Jurnal Berkala Akuntansi Dan Keuangan Indonesia.

Shandy Utama, A. (2018). Pelaksanaan Tanggung Jawab Sosial Dan Lingkungan Perusahaan Berdasarkan UndangUndang Nomor 40 Tahun 2007 Untuk Meningkatkan Kesejahteraan Masyarakat Kecamatan Rumbai Pesisir Kota Pekanbaru. JCH (Jurnal Cendekia Hukum).

Sunaryo, B. A., \& Mahfud, M. K. (2016). Pengaruh Size, Profitabilitas, Leverage dan Umur Terhadap Pengungkapan Tanggungjawab Sosial Perusahaan (Studi Empiris Perusahaan Manufaktur yang Listing Di Bei Tahun 2010 - 2013). Diponegoro Journal of Management.

Susanto, B., \& Ramadhani, T. (2016). FaktorFaktor yang Memengaruhi Konservatisme (Studi Pada Perusahaan Manufaktur yang Terdaftar Di Bei 20102014). Jurnal Bisnis dan Ekonomi.

Swingly, C., \& Sukartha, I. (2015). Pengaruh Karakter Eksekutif, Komite Audit, Ukuran Perusahaan, Leverage dan Sales Growth pada Tax Avoidance. E-Jurnal Akuntansi.

Wulandari, I. A., Machmuddah, Z., \& Utomo, S. D. (2016). Manajemen Laba, CSR Disclosure dan Kinerja Keuangan. Prosiding Simposium Nasional Akuntansi XIX. 
JRAK, Volume 16, No.2 Agustus 2020 